\title{
THE INFLUENCE OF EXTRACELLULAR THYROXINE-BINDING PROTEIN UPON THE ACCUMULATION OF THYROXINE BY TISSUE SLICES ${ }^{1,2}$
}

\author{
By NORBERT FREINKEL, ${ }^{3}$ SIDNEY H. INGBAR, AND J. THOMAS DOWLING 4 \\ WITH THE TECHNICAL ASSISTANCE OF BARBARA R. FINE
(From the Thorndike Memorial Laboratory, Second and Fourth Medical Services (Harvard), Boston City Hospital, and the Department of Medicine, Harvard Medical School, Boston, Mass., and the Howard Hughes Medical Institute, Miami, Florida)

(Submitted for publication February 13, 1956; accepted September 26, 1956)

Within the blood stream, thyroxine is distributed among the plasma proteins according to their relative binding affinities for this material. Thus, circulating thyroxine is principally associated with a moiety intermediate in electrophoretic mobility at $\mathrm{pH} 8.6$ between the $\alpha_{1}$ and $\alpha_{2}$ globulins $(1-6)$. This "thyroxine-binding protein" of plasma $(\mathrm{TBP})^{5}$ has been localized in subfractions of plasma prepared by Method 6 of Cohn, and it has been shown that all subgroups of Fraction IV-4 (especially IV-6 and IV-9) contain TBP greatly in excess of the normal serum proportions (6).

In the present studies, the presence of TBP has been demonstrated in extravascular fluids, and Cohn Fractions (7-9) and tissue slices have been employed for in vitro models designed to assess the possible significance of TBP in the partition of thyroxine between cellular and extracellular phases.

1 This investigation was supported in part by research grant No. A-267 from the National Institute of Arthritis and Metabolic Diseases of the National Institutes of Health, Public Health Service, and in part by the Medical Research and Development Board, Office of the Surgeon General, Department of the Army, under Contract No. DA-49-007-MD-412.

2 Presented in part at the 1955 meeting of the Endocrine Society, June 2-4, 1955, Atlantic City, New Jersey.

${ }^{3}$ Part of this work was performed during the tenure of a Fellowship of the American Cancer Society, Inc., recommended by the Committee on Growth of the National Research Council, 1953-1955.

4 Fellow in Cancer Research of the American Cancer Society, Inc.

5 To date, TBP has not been isolated. Therefore, it cannot be said whether TBP represents a single protein or several proteins which exhibit similar physico-chemical properties in plasma protein mixtures. Furthermore, it remains to be demonstrated whether the affinities for thyroxine result from some specific configurational characteristic of the TBP or merely from a richer endowment with more widely distributed thyraxine-binding residues.

\section{MATERIALS}

Thyroxine. Chromatographically pure preparations of $\mathrm{I}^{131}$-labelled L- and D-thyroxine were obtained from a commercial source ${ }^{6}$ and employed within three days of their arrival in the laboratory. The initial specific activity of the D-thyroxine was $14 \mathrm{mc}$. per mg.; specific activities of L-preparations varied from 30 to $50 \mathrm{mc}$. per mg. In experiments involving both isomers, specific activities were adjusted to identical levels by diluting the labelled L-thyroxine with unlabelled L-thyroxine sodium. ${ }^{7}$

Extracellular fluids. Thoracic duct lymph was obtained from a patient with spontaneous, unexplained chylothorax and femoral lymph was sampled from a patient in whom a right femoral lymphocoele had arisen one week following ligation of the superficial femoral vein. Knee joint fluid was secured from a patient with rheumatoid arthritis and multiple specimens of ascitic fluid were obtained from subjects with hepatic cirrhosis. Samples were collected with local anesthesia and sterile precautions by direct needle aspiration. Sterile specimens of urine were collected from pediatric patients with lipoid nephrosis. Cell counts of all fluids were performed immediately. Fluids were then analyzed for specific gravity, total protein, albumin, protein-bound iodine and stored at $-20^{\circ} \mathrm{C}$ prior to zone electrophoresis.

Tissues. Suitable pieces of heart, liver, and kidney were obtained from sheep, lambs, calves, or beef which had been sacrificed by exsanguination in the local abattoir. Tissues were wrapped in cellophane bags, placed on cracked ice, and transported to the laboratory in Dewar flasks.

Stock protein solutions. Solutions of mercaptalbumin $(7)^{8}$ and of Cohn Fractions II-III, IV-6, and V $(8,9)$ were prepared by dissolving the lyophilized proteins in isotonic saline. These solutions and sera obtained from two fasting euthyroid subjects were adjusted to $\mathrm{pH} 7.4$ and to the same concentration of total protein $(4.0 \pm 0.1$ gm. per cent) and protein-bound iodine (PBI: $10 \pm 0.3$

6 Abbott Laboratories, Oak Ridge, Tenn.

${ }^{7}$ L-thyroxine sodium was 96.2 per cent pure on a dry basis and was kindly supplied by Dr. A. E. Heming of Smith, Kline \& French Laboratories, Philadelphia, Penna.

${ }^{8}$ Mercaptalbumin which had been dialyzed against cysteine to remove mercury was kindly provided by Dr. Margaret J. Hunter of the Department of Biophysical Chemistry of Harvard Medical School. 
$\mu g$. per cent) by the addition of appropriate quantities of $0.3 \mathrm{~N} \mathrm{NaOH}$ or $\mathrm{HCl}, 0.15 \mathrm{~N} \mathrm{NaCl}$, and powdered L-thyroxine sodium. ${ }^{7}$ Values for total protein and PBI were verified by chemical analysis.

Thyroxine-binding moieties in these stock protein solutions were compared by the zone electrophoretic and saturation techniques which have been described previously (6). Thus, the relative abundance of primary (i.e., TBP) and secondary (i.e., albumin, etc.) thyroxinebinding components in the stock protein solutions could be graded as follows:

$\begin{array}{lcc}\text { Stock solution } & \begin{array}{c}\text { Primary } \\ \text { carriers }\end{array} & \begin{array}{c}\text { Secondary } \\ \text { carriers }\end{array} \\ \text { Cohn Fraction IV-6 } & +++++ & 0 \\ \text { Serum } & +++ & ++ \\ \text { Cohn Fraction V } & \pm & +++ \\ \text { Mercaptalbumin } & 0 & +++ \\ \text { Cohn Fraction II-III } & 0 & \pm\end{array}$

Since freeze-thawing does not alter TBP activity (6), the stock solutions were stored at $-20^{\circ} \mathrm{C}$ and aliquots were removed for the preparation of suspending media.

Suspending media. For in vitro studies with tissue slices, Krebs-Ringer-Phosphate (KRP) (10) buffered at $\mathrm{pH} 7.4$ and modified to contain $8.3 \mathrm{mM}$ glucose and 0.8 $\mathrm{mM} \mathrm{CaCl}{ }_{2}$ per liter were employed. Fresh solutions of KRP, both with and without supplemental protein (KRP + Prot., KRP-O-Prot.), were prepared for each experiment. KRP + Prot. mixtures were obtained by substituting the appropriate stock protein solution (v.s.) for an equivalent volume of $\mathrm{NaCl}$. Such use of stock protein solutions facilitated the preparation of multiple KRP + Prot. media of identical $\mathrm{pH}$, total protein, and PBI. In the KRP-O-Prot., total organic iodine was adjusted to levels corresponding to those in the KRP + Prot. by the addition of powdered L-thyroxine sodium. ${ }^{7}$

The same two batches of stock protein solutions were used in the suspending media of all of the experiments reported below.

\section{METHODS}

Protocols of individual experiments will be outlined in the "Results" section. General experimental procedures were as follows:

Analytical techniques. Paper electrophoresis was performed with apparatus and techniques described elsewhere (6). Concentrations of total protein were determined, in duplicate, by a modified biuret method (11) standardized by $\mathrm{Kjeldahl}$ determination of nitrogen in reference solutions of human albumin. Concentrations of albumin were measured, in duplicate, by the colorimetric, dye-absorption method of Rutstein, Ingenito, and Reynolds (12). A micro-Kjeldahl method was employed for analysis of total nitrogen in duplicate aliquots of tissue slices. Protein-bound iodine was estimated by the alkaline ash method of Barker, Humphrey, and Soley (13)..$^{9}$

Extracellular fluids. To undiluted 1-ml. specimens of lymph, nephrotic urine, knee joint fluid, and ascitic fluid,

${ }^{9}$ Iodine analyses were performed by Bio-Science Laboratories, Inc., 2231 Carmelina Avenue, Los Angeles 64, Calif.
$0.06 \mu \mathrm{g}$. of L-thyroxine labelled with $1.8 \mu \mathrm{c}$. of $\mathrm{I}^{121}$ were added. Joint fluids were further supplemented with 75 units per $\mathrm{ml}$. of hyaluronidase. The radioactive extracellular fluids were incubated for twenty minutes at room temperature; $0.020-\mathrm{ml}$. aliquots were then applied directly onto Whatman No. 3 filter paper for zone-electrophoresis at 110 volts. Studies were performed at $\mathrm{pH} 8.6$ in a barbituric acid-sodium barbiturate buffer, $\mathrm{r} / 20.5$, and at $\mathrm{pH} 4.5$ in an acetic acid-sodium acetate buffer, $\mathrm{r} / 20.1$.

Tissue incubation. Slices of heart, liver, and kidney cortex, 0.3 to $0.4 \mathrm{~mm}$. in thickness, were prepared with a Stadie-Riggs microtome and placed in chilled $0.15 \mathrm{~N}$ $\mathrm{NaCl}$. Prior to weighing, the slices were successively dipped into three portions of fresh saline in order to remove adherent blood. Tissues were quickly blotted, weighed on a torsion balance, and introduced into $2.7 \mathrm{ml}$. of suspending medium contained within the main compartment of chilled Warburg flasks. Within any single experiment, the tissue content of individual vessels did not differ by more than $\pm 10 \mathrm{mg}$. Representative slices were saved for nitrogen analyses. Three-tenths $\mathrm{ml}$. of saline solutions containing 10 to $30 \mu \mathrm{c}$. of $\mathrm{I}^{131}$-thyroxine per ml. were measured into the side-arms of the Warburg flasks. Preliminarily, these solutions had been adjusted to the same $\mathrm{pH}$, and, with unlabelled thyroxine, to the same content of organic iodine as the KRP within the main compartments. The use of non-protein media within the side-arms of all of the flasks was designed to standardize the adsorption of radioactivity to glassware (6) during the preparative manipulations.

After the addition of $0.2 \mathrm{ml}$. of 10 per cent potassium hydroxide to the center well, flasks were placed in a thermostatically controlled water bath at $38^{\circ} \mathrm{C}$ and shaken at 112 cycles per minute. Gas spaces were flushed for five minutes with 100 per cent oxygen. Side-arms were emptied into the main compartments at timed intervals following fifteen minutes of temperature equilibration. Manometric techniques were as described elsewhere (14). Oxygen consumption $\left(\mathrm{QO}_{2}\right)$ was derived as cu. mm. $\mathrm{O}_{2}$ per hour per mg. of initial wet weight of tissue.

Where more than nineteen flasks were required for a single experiment, tissues were incubated in $30-\mathrm{ml}$. beakers in the Dubnoff Shaking Incubator (shaking rate: 104 per minute ; gas phase : 100 per cent oxygen; temperature: $38^{\circ} \mathrm{C}$ ), and $0.3-\mathrm{ml}$. aliquots of radiothyroxinesaline solutions were directly introduced into the beakers following temperature equilibration.

Flasks were removed one hour after the "tipping-in" of radioactivity. Slices were blotted on filter paper, weighed on a torsion balance, and digested in $2 \mathrm{~N} \mathrm{NaOH}$. Suspending solutions were centrifuged immediately and residual radioactivity was determined from $1.0-\mathrm{ml}$. aliquots. In the standard experimental procedure no attempt was made to characterize the final radioactivity within the digested slices or the suspending media.

To evaluate the significance of thyroxine degradations during the one-hour standard experimental procedure, chromatographic studies were performed. Incubated slices were quickly frozen on chipped solid carbon dioxide, and then homogenized in $3.0 \mathrm{ml}$. of distilled water con- 
taining $10^{-3} \mathrm{M}$ propylthiouracil. One $\mathrm{ml}$. of the homogenate was removed for assay of total radioactivity; the remainder was acidified to $\mathrm{pH} 3.0$ with $10 \mathrm{~N} \mathrm{H}_{2} \mathrm{SO}_{4}$ and extracted three times with 2-ml. portions of $\mathrm{n}$-butanol. The butanol extracts were pooled; powdered propylthiouracil ( 3 to $5 \mathrm{mg}$.) was added, and the volume was reduced with a stream of nitrogen at room temperature. The residues were applied onto thin strips of Whatman No. 1 filter paper for forty-eight hours of descending one-dimensional chromatography at $20.0+0.5^{\circ} \mathrm{C}$ in isopentanol saturated with $6 \mathrm{~N} \mathrm{NH}_{4} \mathrm{OH}$. This solvent system separates thyroxine from triiodothyronine, as well as from inorganic iodide and iodinated tyrosines (15). Developed strips were counted with a self-recording automatic strip-scanner and the percentage of the total radioactivity which migrated like unlabelled L-thyroxine carrier was determined. Measured aliquots of the suspending media were similarly treated for a) assay of total radioactivity, and for b) chromatographic fractionation of radioactive components.

In the standard experimental procedure, total recovery of radioactivity was derived as the sum of the counts remaining within the medium (counts per ml. medium $\times$ 3) plus the counts within the slices. Cellular "uptake" was expressed as a percentage of this total recovery (i.e., tissue counts $\times 100 /$ total recovered counts). In the chromatographic studies, total counts within the slices and media were corrected for radioactive components other than thyroxine in order to derive corrected cellular "uptakes."

Attempts to express "uptake" as a percentage of the theoretically added number of counts or as an absolute number of counts without regard to the radioactivity of the medium were complicated by variable adsorption of radiothyroxine (a) to the side-arms of the Warburg vessels prior to "tipping-in," especially at acidic $\mathrm{pH}$; or (b) to the walls of the main compartment of the Warburg vessels following "tipping-in," especially into KRP-OProt. media. Since the precise contribution of glass surfaces to thyroxine distribution cannot be quantified, it was felt that "uptake," related to total recovery, best represented the partition of the residual radioactivity between a fluid extracellular phase and a solid tissue phase.

Cellular "uptake" was not corrected for adherent extracellular fluid. : Arbitrary selection of a correction factor was not considered justified. Moreover, correction for extracellular fluid would not have altered relative intercomparisons and would have affected absolute values only slightly. For example, even if $200 \mathrm{mg}$. of tissues suspended in $3 \mathrm{ml}$. of fluid were contaminated with 40 per cent by weight of extracellular fluid, the maximum apparent "uptake" due to extracellular occlusions could not exceed 2.7 per cent of the total radioactivity [ $(0.200 \times$ $0.40 / 3.0) \times 100]$. During true cellular accumulation, the suspending medium is depleted of radioactivity, and hence the potential occlusive error becomes even less. Nonetheless, it should be noted that the 2 to 3 per cent "uptakes" which were observed in some of the studies with KRP Fraction IV -6 may have represented predominantly extracellular radioactivity.
Radioactive assay. Electrophoretograms and chromatographic strips were scanned for radioactivity in an automatic strip scanner utilizing a gas-flow counter. The graphic recordings of radioactivity obtained from each strip were traced on hard paper of uniform thickness. The total curves and individual peaks were cut from the tracings and weighed, using a semi-automatic analytic balance of $0.05 \mathrm{mg}$. sensitivity. This permitted rapid and accurate integration of the total radioactivity and that of the individual peaks.

In slice experiments, aliquots of the suspending media and of the digested or homogenized tissues were diluted in volumetric flasks. To minimize adsorption to glassware, all dilutions were immediately made alkaline to phenolphthalein and supplemented with small amounts of human serum albumin and unlabelled thyroxine. Planchets were prepared and counted with a mica end-window GeigerMuller tube connected to an automatic, self-recording sample changer. Geometry and self-adsorption characteristics were kept constant.

Other liquid samples were counted directly in well-type scintillation counters containing crystal detector heads of thallium-activated sodium iodide.

In all radioactive analyses, sufficient counts were observed to reduce the probable error of the measurement to less than \pm 3 per cent.

\section{RESULTS}

\section{Thyroxine-binding components in extracellular fluids}

All fluids contained a thyroxine-binding component which simulated the zone-electrophoretic characteristics of the TBP of plasma $(1-6,14,16)$ (Figure 1). Thus, part of the added radiothyroxine migrated intermediate between the $\alpha$ and the $\alpha_{2}$ globulins at $\mathrm{pH} 8.6$ and towards the anode at $\mathrm{pH}$ 4.5. In all extracellular fluids, albumin constituted the chief secondary carrier for thyroxine.

Unbound thyroxine does not display comparable mobilities under these conditions (6). Significant contamination of extracellular fluids with blood may be excluded on the basis of the low red blood cell counts (Figure 1).

\section{The interaction of thyroxine with tissue slices}

During incubation in vitro, surviving slices accumulated radiothyroxine from the suspending media. Experiments were performed with slices of lamb, sheep, calf and beef kidney cortex, heart, and liver. In all studies, radioactive "uptakes" were greatest in KRP-O-Prot. and varyingly reduced in KRP + Prot. At equivalent concentrations of the total protein, the KRP + Prot. mix- 
tures impaired cellular "uptake" in direct proportion to their content of specific thyroxine-binding moieties. Thus, at protein concentrations ranging from 0.5 to $2.0 \mathrm{gm}$. per cent, the inhibitory potentials of the KRP + Prot. mixtures could be graded as follows: KRP + Fract. IV- $6>\mathrm{KRP}$ + serum $>$ KRP + Fract. V or mercaptalbumin $>\mathrm{KRP}+$ Fract. II-III. ${ }^{10}$ Table I represents

10 The differences between KRP-O-Prot. and KRP + Fract. II-III may be more apparent than real. The absolute cellular accumulations of radioactivity (i.e., counts per gm.) did not differ markedly in these two media. However, total recovery of radioactivity was consistently greater in KRP + Fract. II-III. Therefore, "uptake," when expressed as a percentage of the total recovery, was less in KRP + Fract. II-III than in KRP-O-Prot. one such experiment wherein all vessels were incubated in triplicate in order to assess the reproducibility of "uptakes" in the standard experimental procedure.

Chromatographic fractionation of sheep liver, kidney, and heart slices and KRP + Prot. and $\mathrm{KRP}-\mathrm{O}-\mathrm{Prot}$. media following one hour of incubation revealed that unaltered radiothyroxine constituted more than 80 per cent of the total radio-

It is possible that the inclusion of Fract. II-III in the suspending medium may have only impaired the adsorption of radioactivity to glassware without altering absolute cellular accumulation. On the other hand, all of the other KRP + Prot. media effected a reduction of the absolute as well as the fractional "uptake" of radiothyroxine from tiie extracellular pliase.

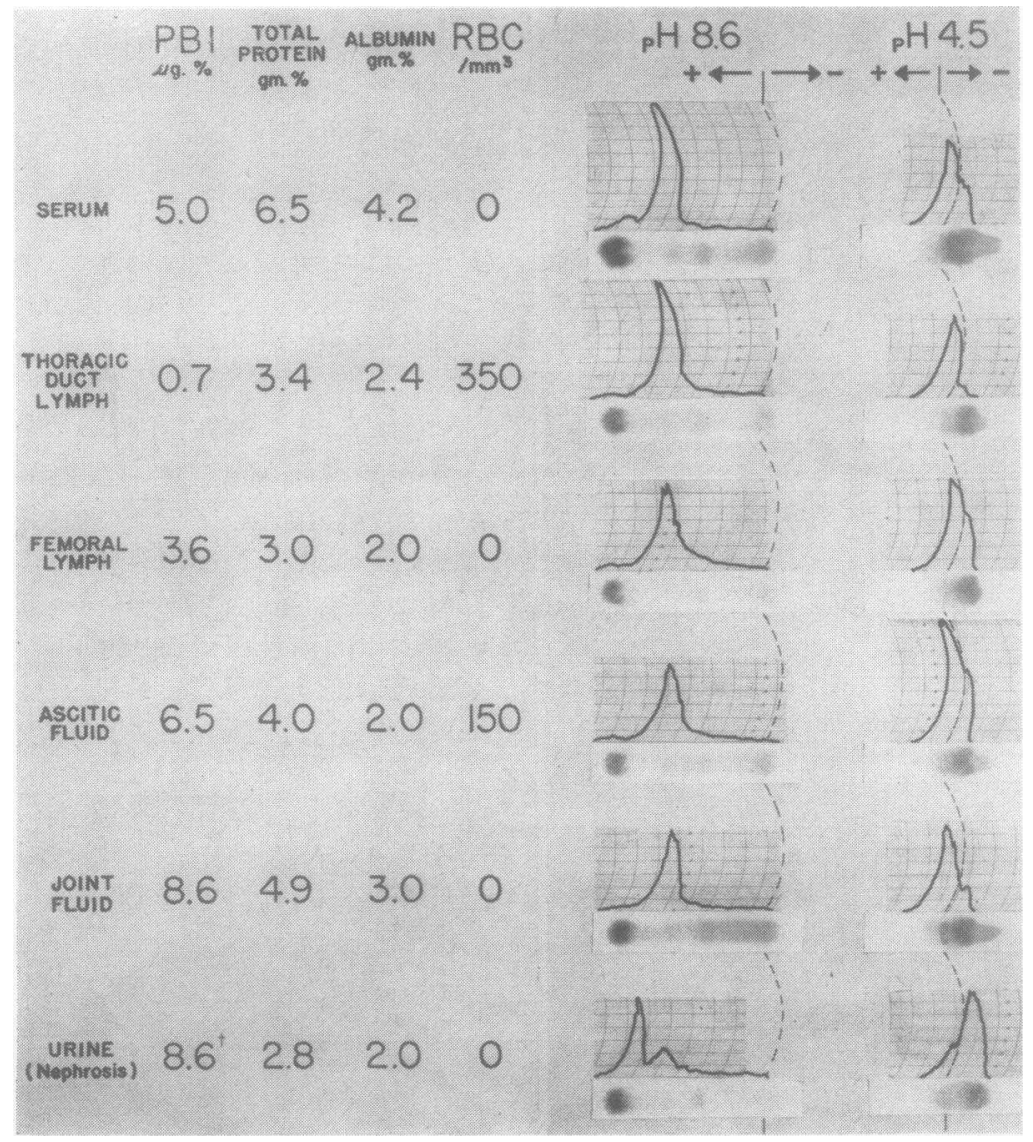

Fig. 1. Thyroxine-Binding By Extracellular Flitids

The darkened lines represent the scanning pattern of the distribution of radioactivity following paper electrophoresis at $\mathrm{pH} 8.6$ and at $\mathrm{pH} 4.5$. Electrophoretograms stained with bromphenol blue have been reproduced underneath the scanning patterns. However, staining detail has been lost in the photographic reproduction. Values for protein-bound iodine (PBI) represent endogenous levels prior to supplementation with $\mathrm{I}^{131}$-labelled L-thyroxine. $\dagger$ Total iodine in the nephrosis urine: $15.4 \mu \mathrm{g}$. per cent. 
TABLE I

"Uptake" of L-radiothyroxine by surviving slices of lamb kidney cortex: Reproducibility of "uptake" measurements *

\begin{tabular}{lcc}
\hline \hline $\begin{array}{c}\text { Suspending } \\
\text { medium }+\end{array}$ & $\begin{array}{c}\text { "Uptake" } \\
\text { (\% of total recovery) }\end{array}$ & $\mathrm{QO}_{2} \dagger$ \\
\hline O-Prot. & $34.6,33.4,35.6$ & 1.19 \\
Fract. II-III & $20.2,24.4,23.0$ & 1.25 \\
Mercaptalb. & $13.0,12.6,11.8$ & 1.22 \\
Serum & $8.2,8.2,7.0$ & 1.38 \\
Fract. IV-6 & $3.4,3.4,3.2$ & 1.42 \\
\hline
\end{tabular}

* Tissues incubated for one hour in triplicate; total protein in KRP + Prot. media ranged from 1.5 to $1.6 \mathrm{gm}$. per cent ; nitrogen content of tissue slices averaged $4.31 \mathrm{mg}$.

$\dagger \mathrm{QO}_{2}$ is derived as cu. mm. $\mathrm{O}_{2}$ per hour per mg. of initial wet weight and represents average of triplicate analyses.

activity within all systems. Radioactive breakdown products partitioned between slices and media in such a fashion so that "uptakes" which had been corrected for radioactive components other than thyroxine did not differ significantly from uncorrected "uptakes" based on the total recovered radioactivity (Table II). The finding that the breakdown of thyroxine is minimal during one hour of incubation in vitro is in accord with the observations of Albright, Larson, and Tust in the rat (17) and supports the use of uncorrected "uptakes" in the standard experimental procedure.

To evaluate the kinetics of cellular accumulation, tissues were incubated in the Dubnoff apparatus and multiple analyses were secured at timed intervals. "Uptake" was not instantaneous, but rather slowly approached ultimate limiting values in all media. At all times throughout the equilibration period, cellular "uptakes" were proportional to the thyroxine-binding components in the suspending media (Figure 2). Although the potential magnitude of thyroxine degradation during prolonged incubation has not been assessed, it should be noted that the qualitative interrelationships after 360 minutes of incubation did not differ from the findings at 30 minutes.

Characteristics of the cellular/extracellular distribution of thyroxine in vitro

Reversibility: Tissues were suspended in $3 \mathrm{ml}$. of KRP-O-Prot. containing I I31-labelled L-thyroxine. Following one hour of incubation, control flasks were removed. To the remaining flasks were added $1 \mathrm{ml}$. of either KRP-O-Prot. or KRP
TABLE II

"Uptake" of L-radiothyroxine by surviving slices of lamb tissues: Corrected vs. standard "uptake" *

\begin{tabular}{llrr}
\hline \hline & & \multicolumn{2}{c}{ “Uptake" } \\
\cline { 3 - 4 } Tissue & Suspending & Standard $†$ & Corrected \\
\hline Kidney & O-Prot. & 49.3 & 48.6 \\
cortex & Fract. II-III & 26.6 & 24.8 \\
& Fract. IV-6 & 3.9 & 3.7 \\
& O-Prot. & 49.8 & 48.2 \\
Liver & Fract. II-III & 32.1 & 30.1 \\
& Fract. IV-6 & 5.1 & 4.4 \\
& O-Prot. & 74.3 & 80.0 \\
Heart & Fract. II-III & 32.8 & 34.8 \\
& Fract. IV-6 & 4.9 & 4.5 \\
& & & \\
\hline
\end{tabular}

* Tissues incubated for one hour; total protein in KRP + Prot. media ranged from 1.4 to $1.5 \mathrm{gm}$. per cent.

† Standard "Uptake": Tissue I ${ }^{131}$ expressed as a percentage of total recovered radioactivity.

‡ Corrected "Uptake": Tissue radioactivity expressed as a percentage of chromatographically-identified radiothyroxine within slices and media.

+ Fract. IV-6 (5.9 gm. per cent). Paired groups of flasks were removed at 20-minute intervals during the next hour. Analysis revealed that the introduction of KRP + Prot. was followed by a rapid removal of radioactivity from the slice (Figure 3 ). The tissue content of $\mathrm{I}^{131}$ approached a low, apparently limiting value at 40 minutes. Where only KRP-O-Prot. had been added, thyroxine distribution was not significantly altered.

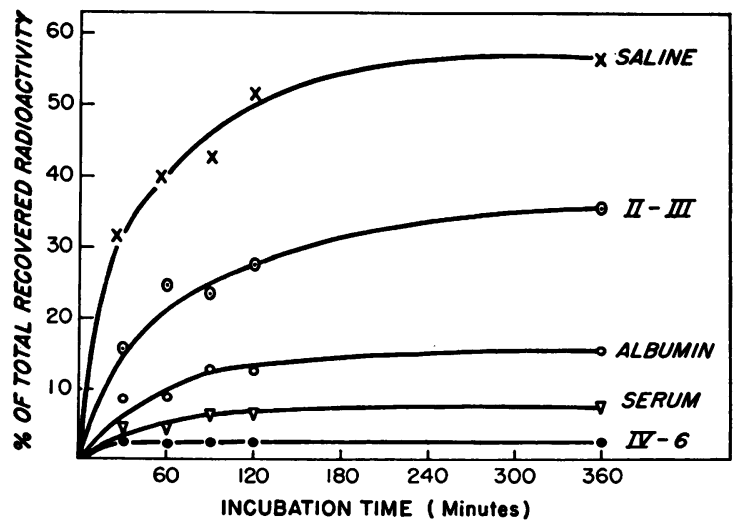

Fig. 2. "Uptake” of L-Radiothyroxine by Surviving Slices of Calf Heart

"Saline" refers to KRP-O-Prot. and the "II-III, albumin, serum and IV-6" refer to the various KRP + Prot. suspending media. Cellular "uptake" is expressed as a percentage of the total recovered radioactivity. Nitrogen content of the incubated slices ranged from 3.42 to 3.76 $\mathrm{mg}$; total protein in the KRP + Prot. mixtures varied from 1.4 to 1.5 gram per cent. 


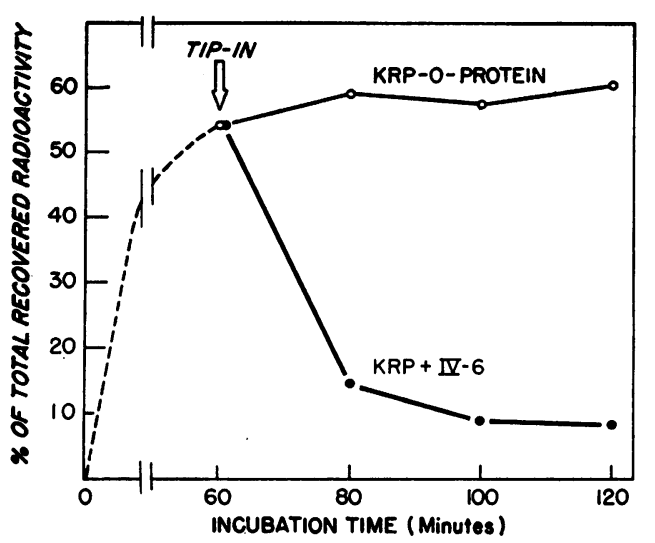

Fig. 3. Reversibility of the Tissue "Uptake" of L-RADIOTHYROXINE

Slices of sheep heart were incubated for one hour in KRP-O-Prot. containing I ${ }^{181}$-labelled L-thyroxine. Control flasks were removed and 1-ml. portions of non-radioactive KRP-O-Prot. or KRP + Fract. IV-6 were added to the remaining flasks.

Protein concentration: When the concentration of Fraction IV-6 in the suspending medium was kept constant and slice weight was varied, cellular "uptake" varied in relation to tissue mass. Conversely, when slice weight was kept constant, and IV-6 was varied, cellular "uptake" was inversely proportional to the extracellular TBP (Figure 4).

Similar relationships have been observed with simple plasma protein mixture (6). To document the parallelisms, paired experiments were per-
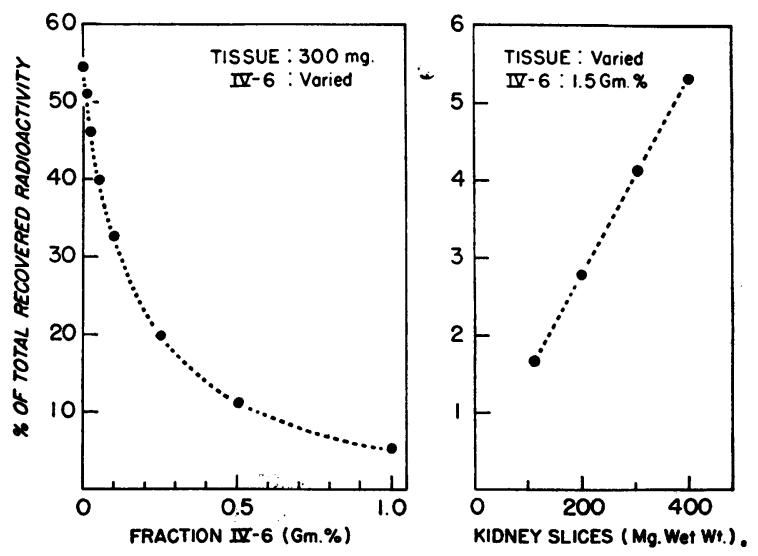

Fig. 4. "Uptake" of L-Radiothyroxine by SURviving Slices of Lamb Kidney Cortex

The effects of yariations in tissue mass and in the concentrations of extracellular KRP + Fract. IV-6 are demonstrated. Nitrogen content of the kidney slices averaged $1.72 \mathrm{mg}$. $\mathrm{N}$ per $100 \mathrm{mg}$. of initial wet weight. formed wherein 1) varying amounts of Fraction IV-6 were incubated with constant amounts of surviving tissue slices and the distribution of radiothyroxine was quantified by direct analysis, and 2 ) varying amounts of IV-6 were incubated with constant amounts of mercaptalbumin and the distribution of radiothyroxine was assessed by paper electrophoresis. In both systems, the partition of thyroxine was conditioned by the availability of TBP (Figure 5).

Thyroxine concentration: L-thyroxine within all suspending media was increased by the addition of unlabelled thyroxine. Concentrations of cellular and extracellular proteins were kept constant. This resulted in an augmented percentile "uptake"

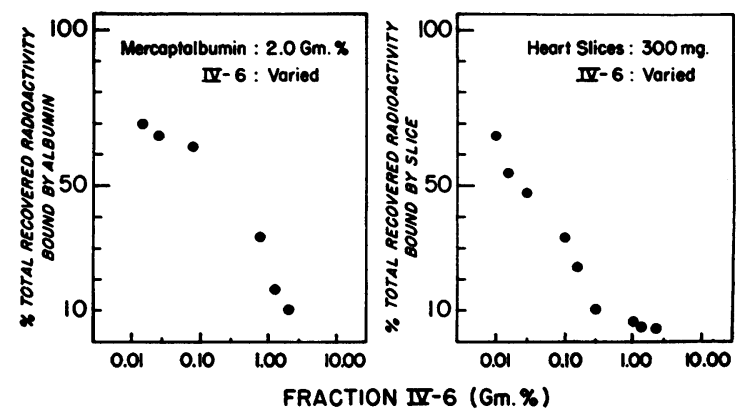

Fig. 5. Similarities in 1 he Distribution of Thyroxine in Mixtures of Plasma Proteins and in Cellular Systems

All solutions were adjusted with L-thyroxine to an initial concentration of $0.15 \mu \mathrm{g}$. of organic iodine per $\mathrm{ml}$. Heart slices were obtained from lambs and averaged $1.68 \mathrm{mg}$. of nitrogen per $100 \mathrm{mg}$. of initial wet weight.

and in a greater absolute accumulation of thyroxine than might be anticipated on the basis of a fixed cellular/extracellular distribution equilibrium (Table III). Systems containing KRP + Fract. IV -6 were least affected by the added thyroxine. Thus, in the experiment depicted in Table III, the change in cellular "uptake" in KRP $+\mathrm{IV}^{T}-6$ is of questionable significance although the increases in all other media exceed the limits of methodological variability. Enhancement of "uptake" was most pronounced at low concentrations of extracellular proteins. Completely protein-free media were not achieved. Protein concentrations of 20 to 30 mg. per cent (with slices of kidney and heart) or 100 to $150 \mathrm{mg}$. per cent (with slices of liver) were frequently demonstrated in suspending media following incubation in KRP-O-Prot. Whether 
TABLE III

"Uptake" of L-radiothyroxine by surviving slices of lamb kidney cortex: Relationship to thyroxine concentration *

\begin{tabular}{|c|c|c|}
\hline \multirow{2}{*}{$\begin{array}{c}\text { Suspending } \\
\text { medium }+\end{array}$} & \multicolumn{2}{|c|}{$\begin{array}{c}\text { "Uptake" } \\
\text { (\% of total recovery) }\end{array}$} \\
\hline & Low Tx.† & High Tx. \\
\hline $\begin{array}{l}\text { O-Prot. } \\
\text { Fract. II-III } \\
\text { Fract. V } \\
\text { Serum } \\
\text { Fract. IV-6 }\end{array}$ & $\begin{array}{r}53.9 \\
26.1 \\
18.4 \\
8.1 \\
4.1\end{array}$ & $\begin{array}{r}68.1 \\
45.9 \\
25.8 \\
16.3 \\
4.8\end{array}$ \\
\hline
\end{tabular}

* Tissues incubated for one hour; total protein in KRP + Prot. media was $0.5 \mathrm{gm}$. per cent; nitrogen content of tissue slices averaged $4.40 \mathrm{mg}$.

† Low Tx.: Chemically-estimated protein-bound iodine in KRP + Prot. media ranged from 2.9 to $3.4 \mu \mathrm{g}$. per cent. $¥$ High Tx.: Chemically-estimated protein-bound iodine in KRP + Prot. media ranged from 9.7 to $11.0 \mu \mathrm{g}$. per cent.

these proteins originated as adherent plasma proteins or were leached into the medium during incubation cannot be stated.

Thyroxine isomers: Differences in the metabolism of thyroxine isomers in vivo were studied in a euthyroid volunteer and in a patient with untreated primary myxedema. Intravenous doses of $70 \mu \mathrm{c}$. $\left(6 \mu \mathrm{g}\right.$.) of $\mathrm{I}^{131}$-labelled D-thyroxine and $50 \mu \mathrm{c}$. $\left(2 \mu \mathrm{g}\right.$.) of $\mathrm{I}^{131}$-labelled L-thyroxine were given to each subject at intervals of six weeks. Daily blood samples were secured for nine days following each administration. In both subjects, the early dilution (cf. blood level Day 1) and the subsequent rate of disappearance ( $c f$. blood levels Day 2 to Day 9 ) of D-thyroxine exceeded that of the L-isomer (Figure 6). Rall, Robbins, Becker,

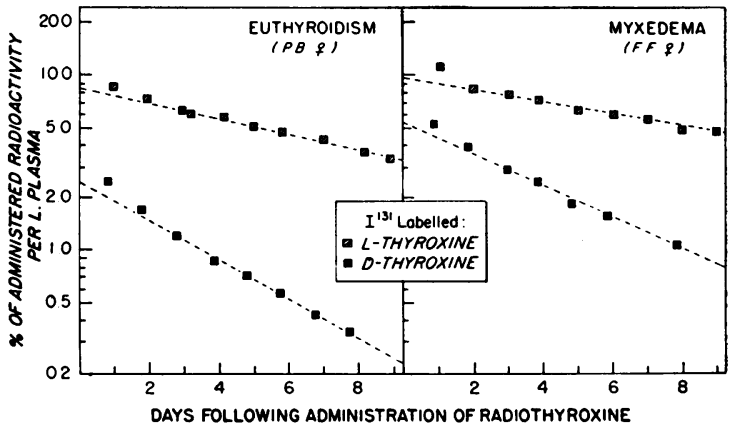

Fig. 6. The Disappearance of Labelled Thyroxine IsOMERS From the Circulation of Human SubJeCtS

and Rawson (18) have reported similar observations.

For in vitro studies, tissue slices were incubated in "two isomer" and in "one isomer" systems. In the former, protein and non-protein KRP preparations were adjusted to an organic iodine content of $0.07 \mu \mathrm{g}$. per ml. with unlabelled L-thyroxine and then supplemented with $0.06 \mu \mathrm{g}$. per ml. of either D- or L-radiothyroxine. The isomeric mixtures were designed to simulate the conditions in vivo which obtain following the administration of D-thyroxine. In the "one isomer" systems, KRP preparations were supplemented exclusively with $0.14 \mu \mathrm{g}$. per ml. of either D- or L-radiothyroxine. Concentrations of proteins in KRP-Prot. were sufficiently low ( $5 \mathrm{mg}$. per $\mathrm{ml}$.) to minimize the contributions of the endogenous protein-bound iodine. Both the "one isomer" (Table IV) and the "two isomer" (Figure 7) systems yielded

TABLE IV

"Uptake" of thyroxine isomers by surviving slices of lamb kidney cortex: Relationship to oxygen tension *

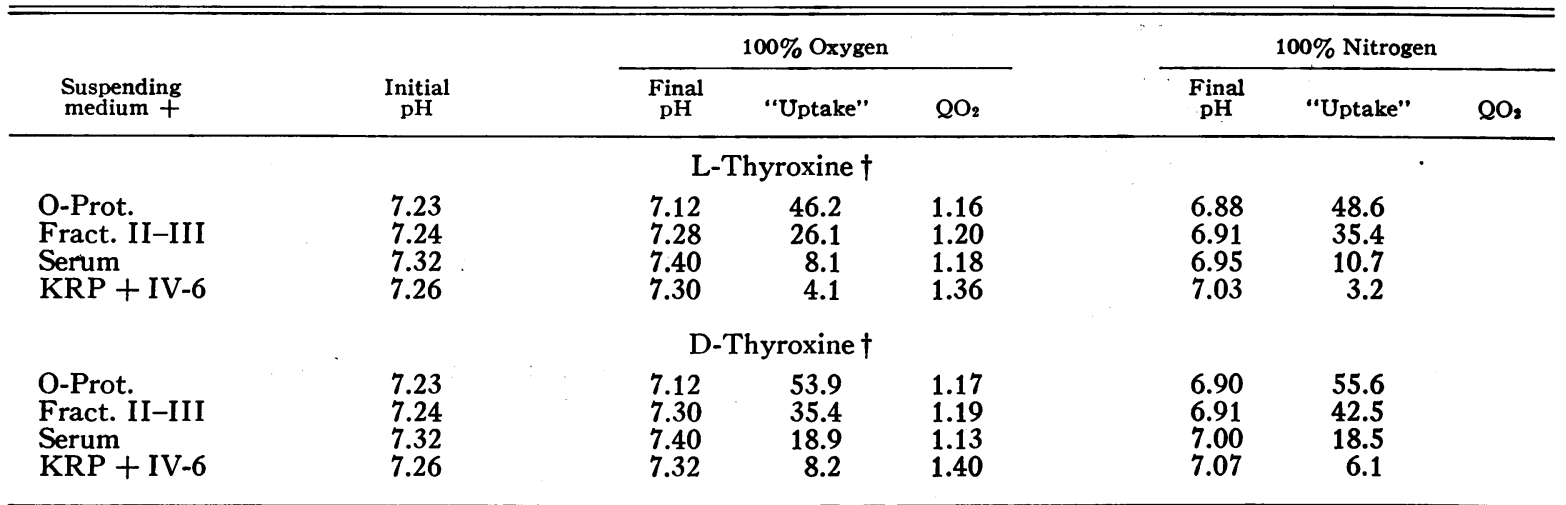

* Tissues incubated for one hour; total protein in KRP + Prot. media was 0.5 gm. per cent, "Uptake" calculated as percentage of total recovered radioactivity.

$\dagger$ “One isomer systems" (see text): Media supplemented to contain $0.14 \mu \mathrm{g}$. per $\mathrm{ml}$. of either D- or L-radiothyroxine. 


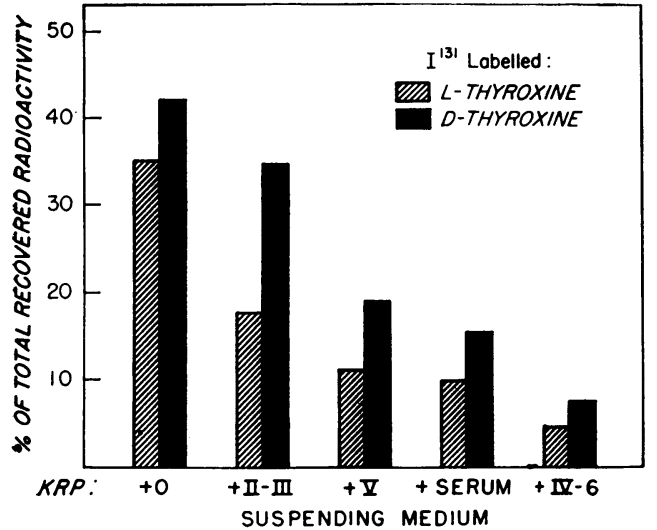

Fig. 7. "Uptake” of Thyroxine Isomers by Surviving Slices of Lamb Kidney Cortex

All KRP media were adjusted with unlabelled L-thyroxine to contain $0.07 \mu \mathrm{g}$. of organic iodine per $\mathrm{ml}$. "Two isomer systems" (see text) were prepared by supplementing the suspending solutions with $0.06 \mu \mathrm{g}$. per $\mathrm{ml}$. of either D- or L-radiothyroxine. Concentrations of total proteins in the KRP + Prot. mixtures ranged from 1.9 to $2.0 \mathrm{gm}$. per cent.

similar results. The percentile "uptake" of the D-thyroxine varied inversely with the abundance of thyroxine-binding moieties in the suspending media. Cellular accumulation of D-radiothyroxine was greatest in KRP-O-Prot. and least in KRP + IV-6. The "uptake" of the D-material exceeded that of the L-isomer in all media. Differences in the "uptake" of the isomers were least marked in $\mathrm{KRP}-\mathrm{O}-\mathrm{Prot}$.

pH: KRP-O-Prot. and KRP + Fract. IV-6 media were adjusted to varying $\mathrm{pH}$ levels prior to the introduction of tissue slices. In KRP + Fract. IV-6, cellular "uptake" varied inversely with $\mathrm{pH}$ (Figure 8). For kidney cortex and heart, $\mathrm{pH}$ dependencies were neither as marked nor as consistent in the KRP-O-Prot. systems.

In all suspending media, the total recovery of radioactivity was consistently diminished at low $\mathrm{pH}$. This enhances the significance of the increased cellular "uptakes" from acidic KRP + Fract. IV-6, since the reverse might be anticipated on the basis of the relationship between "uptake" and thyroxine concentration which has been described above.

\section{Metabolic relationships in vitro}

The effect of cellular "uptake" upon cellular respiration: Cellular respiratory activity was un- altered by variations in cellular "uptake." The profound changes in "uptake" which were effected by substituting KRP-Prot. for KRP-O-Prot., or by increasing the extracellular concentration of thyroxine, did not significantly affect $\mathrm{QO}_{2}$.

However, the presence of IV-6 in the suspending medium was often, although not invariably, associated with an immediate and a sustained fifteen to thirty per cent augmentation of cellular respiration. This was unrelated to the absolute amount of thyroxine within the system. In the experiment which is partly pictured in Figure 4, the $\mathrm{QO}_{2}$ values of surviving kidney slices in KRP containing $40,20,15,10,2.5,0.5,0.1$, or $0.0 \mathrm{mg}$. per $\mathrm{ml}$. of Fraction IV-6 were 1.73, 1.50, 1.51, 1.38, 1.29, $1.32,1.32$ and 1.33 , respectively. The concomitant respective "uptakes" were $3.0,3.4,4.2,5.2,20.0$, 39.0, 51.1, and 54.5 per cent. Occasional immediate enhancement of respiration also occurred in media which had been supplemented with Fraction $\mathrm{V}$ or serum. These inconstant effects of certain proteins could not be correlated with any variant of the incubation procedure, nor could they be duplicated with triiodothyronine. The phenomenon remains unexplained and is currently under investigation.

The effect of cellular metabolism upon cellular "uptake": Substitution of 100 per cent nitrogen for 100 per cent oxygen in the standard experimental procedure did not produce consistent al-

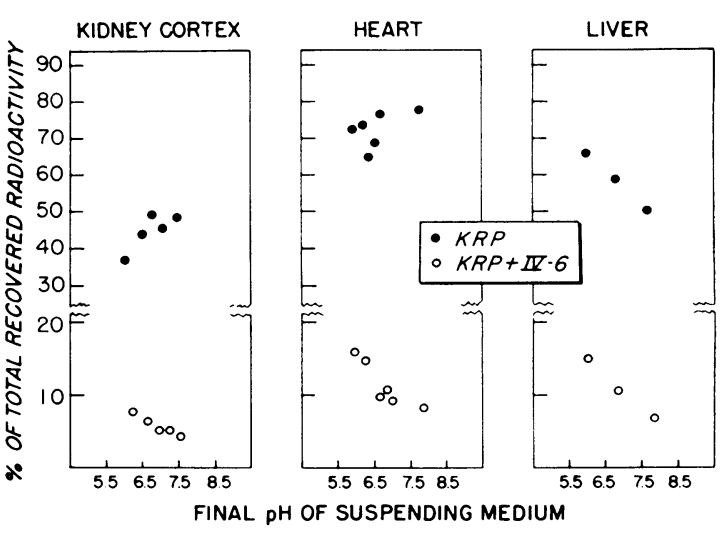

Fig. 8. The Effect of pH upon the "Uptake" of L-Radiothyroxine by Surviving Slices of Lamb Tissues

Final $\mathrm{pH}$ values above 7.5 were obtained by substituting Tris (hydroxymethyl) aminomethane $(0.1 \mathrm{M})$ for phosphate buffer in the preparation of the most alkaline suspending media. 
terations in the "uptake" of radiothyroxine by surviving slices (Table IV). When surviving slices were incubated for one hour at $8^{\circ} \mathrm{C}$ rather than at $38^{\circ} \mathrm{C}$, "uptakes" were significantly depressed (Table V). "Uptakes" were not impaired by boiling duplicate sets of weighed slices for ten minutes prior to incubation (Table V). The "uptakes" by boiled tissues from KRP-OProt. and KRP + Fract. II-III media were even greater than those of unboiled controls. The enhancement of "uptake" may have resulted from loss, during boiling, of those cellular or interstitial thyroxine-binding components which are leached into the incubating medium during the standard experimental procedure (v.s.), and which ordinarily augment the thyroxine-binding capacity of the extracellular phase. However, alternative explanations cannot be excluded.

\section{DISCUSSION}

Certain lines of evidence would suggest that the combination of thyroxine with plasma TBP may be of importance in the extravascular disposition of thyroxine. In an earlier report (19) it had been noted that the values for the turnover and distribution of radiothyroxine in humans $(19,20$ 23) are somewhat similar to those of such macromolecules as labelled plasma proteins (24-27) or highly associated complexes of dye and protein (28). Since that time, Alpers and Rall (29) have reported the presence of plasma TBP in cerebrospinal fluid, and, in the present communication, TBP has been demonstrated in other normal and abnormal extravascular fluids. These recent findings would suggest that plasma TBP, like other plasma proteins, is distributed in a portion of the body waters which includes freelyexchanging intra- and extravascular components. Moreover, the data lend support to the concept of a "thyroxine-space" whose anatomical boundaries may be delimited by the thyroxine-binding protein. It is quite likely that free, unbound thyroxine is involved in the ultimate transcellular exchange of thyroxine. Nonetheless, from the available evidence it may be inferred that extracellular thyroxine is chiefly in association with a plasma protein carrier, and that tissue thyroxine must be abstracted from such a reservoir.

In the present studies, in vitro models were designed to asssess the static factors which may in-
TABLE V

"Uptake" of l-radiothyroxine by slices of sheep kidney cortex: Relationship to temperature and tissue viability*

\begin{tabular}{lcrr}
\hline \hline & \multicolumn{2}{c}{ “Uptake” (\% of total recovery) } \\
\cline { 2 - 3 } $\begin{array}{c}\text { Suspending } \\
\text { medium + }\end{array}$ & \multicolumn{2}{c}{ Surviving slices } & $\begin{array}{r}\text { Boiled } \\
\text { slices }\end{array}$ \\
\cline { 2 - 3 } & $38^{\circ} \mathrm{C}$ & $8^{\circ} \mathrm{C}$ & $38^{\circ} \mathrm{C}$ \\
\hline O-Prot. & 51.8 & 19.0 & 81.7 \\
Fract. II-III & 12.7 & 7.7 & 33.3 \\
Fract. IV-6 & 3.0 & 1.9 & 2.9
\end{tabular}

* Tissues incubated for one hour; total protein in KRP + Prot. media ranged from 1.8 to $1.9 \mathrm{gm}$. per cent.

fluence this partition of thyroxine between cellular and extracellular phases. A high degree of specificity was afforded by the availability of plasma protein fractions of known and varied thyroxinebinding capacities. ${ }^{11}$ Furthermore, by chromatographic techniques it could be demonstrated that during the standard experimental period of one hour, cellular degradation of thyroxine was insufficient to influence appreciably the static distribution phenomena. Thus, simple systems could be devised to characterize a) the cellular "uptake" of thyroxine, b) the relationship between cellular "uptake" and extracellular events.

"Uptake" by tissues in vitro was shown to be dependent upon temperature but inrelated to cellular metabolic activity. Anoxia did not depress "uptake" nor did such drastic procedures as denaturation of tissue proteins by boiling. Thus, it is apparent that the establishment of concentration differentials for thyroxine between slices and suspending media constitutes an equilibrium binding phenomenon rather than an "active" transport.

11 The use of human plasma fractions in association with animal tissues may be questioned. Obviously, systems containing homologous cellular and extracellular phases would have been preferable. This was possible for studies involving KRP + serum. In preliminary experiments, comparable modifications of slice "uptakes" were effected with KRP + Homologous Animal Serum and $\mathrm{KRP}+$ Heterologous Human Serum. For experiments with Cohn Fractions, homologous systems were not feasible. However, studies with animal sera (30) have demonstrated that in sheep, lambs, beef and calves, as in humans, circulating thyroxine is principally associated with a discrete alpha-globulin moiety. Moreover, albumin constitutes the chief secondary carrier for thyroxine in all these species. The gross parallelisms in plasma transport suggest that extravascular distribution phenomena may be similar also, and that heterologous systems may be employed for their qualitative evaluation. 
Crispell and Coleman (31) have reached similar conclusions about the binding of radiothyroxine by intact human red cells (32). As such, it is not surprising that many of the present findings simulate previous observations which were made with mixtures of plasma proteins (6). At that time, it was concluded that thyroxine is distributed among plasma proteins according to a reversible binding equilibrium between a finite amount of TBP and relatively unlimited quantities of secondary carriers of lesser binding affinities. For simplicity, an inert role was assigned to the thyroxine molecule and the binding partition between the competing proteins was described in terms of a twocomponent system. Certainly much of the present data may be formulated in a similar fashion.

First, it has been demonstrated that the "uptake" of thyroxine by surviving slices progressively approaches limiting values. Admittedly, this could represent cellular saturation. However, since the ultimate "uptake" is a function of the protein content of the suspending medium, it seems more likely that the asymptote is determined by some form of distribution equilibrium between cellular and extracellular binding moieties. Secondly, the capacity of extracellular media to diminish the cellular "uptake" of thyroxine is directly proportional to their content of soluble thyroxine-binding proteins (especially TBP). This correlation would indicate that changes in "uptake" are not due merely to non-specific van der Waals' interactions between thyroxine and extracellular macromolecules. Thirdly, thyroxine already bound by the cell can be withdrawn therefrom by the introduction of TBP into the medium, much as the addition of TBP to plasma protein mixtures can recover thyroxine from albumin (6). Finally, as one would expect from equilibrium principles, the distribution of a constant amount of thyroxine can be predictably altered by varying the concentration of either the cellular or the extracellular binding reactants.

In mixtures of plasma proteins, thyroxine can be displaced from TBP onto albumin by the addition of increasing amounts of thyroxine (6). Similarly, cellular "uptake" can be augmented by increasing the concentration of extracellular thyroxine. The findings would indicate that the partition of thyroxine in both systems is conditioned not only by the relative abundance of binding moie- ties, but also by the absolute amount of thyroxine which is to be bound. For mixtures of plasma proteins, this thyroxine-dependent spectrum of distribution equilibria has been attributed to relative saturation of TBP. A similar explanation may be invoked in the slice preparation and it should be noted that truly protein-free suspending media were not achieved even in the KRP-O-Prot. systems. However, it cannot be excluded that some of the enhancement of cellular "uptake" may have resulted from saturation of adsorbing glass surfaces, or from some intrinsic characteristic of cellular binding reactions, which is independent of extracellular proteins.

In some of the other experiments, analogy becomes more complicated. For example, the uptake of D-thyroxine from all suspending media, exceeded that of the L-isomer. Robbins and Rall (33) noted little differences in the binding of thyroxine isomers by TBP. Contrariwise, Larson and Albright (34) reported that plasma TBP binds L-thyroxine much more tenaciously than the $\mathrm{D}$ form. In the face of these contradictory findings it remains to be elucidated whether the preferential tissue accumulation of $\mathrm{D}$-thyroxine in vitro and the more rapid turnover of $\mathrm{D}$-thyroxine in vivo are conditioned solely by extracellular factors.

Similarly, it should be noted that TBP has not yet been isolated, the cellular sites for binding thyroxine have not been defined, and even the isoelectric point for thyroxine has not been determined. Thus, more than descriptive analysis of the increase of cellular "uptake" which occurs in $\mathrm{KRP}+\mathrm{IV}-6$ media at acidic $\mathrm{pH}$ is not warranted. Since thyroxine is an amino acid, and plasma TBP and tissues are protein, electrostatic interactions (35) of all three are theoretically capable of independent and interdependent modifications by $\mathrm{pH}$. $\mathrm{pH}$ may alter not only TBP or cellular binding affinities, but also the configurational characteristics of the thyroxine molecule which make for its binding at the same or at different sites by TBP or cells.

Limitations of the present data should be recognized. The site of cellular "uptake" has not been localized; thus, distinction cannot be made between simple binding onto cell surfaces and "uptake" which reflects penetration to subcellular particles beyond cell-membrane barriers. Moreover, the 
possibility that extracellular proteins may facilitate transcellular flux has not been evaluated. Current investigations in this laboratory are focused in these directions.

For the moment, the precise correlations between the slice studies and the intact animal are conjectural. However, it does not seem unlikely that the in vitro system reproduces the static phenomena which obtain in vivo. Hence, in the whole animal, at any single instant, the partition of thyroxine between cellular and extracellular phases may be conditioned by the absolute concentration of thyroxine, and by the quantitative balance between cellular and extracellular binding moieties. Furthermore, on the basis of the slice experiments, it seems plausible that this partition may be acutely altered by such sequelae of intracellular metabolism as $\mathrm{pH}$ changes independent of fluctuations in the absolute concentration of any of the interacting variables.

In more dynamic terms, thyroxine exchanges in the living animal differ markedly from the onehour slice experiments. In vivo, there is a continuous irreversible removal of thyroxine from the "thyroxine-space" through cellular degradation and fecal losses. This is counterbalanced by the delivery of an equivalent amount of new thyroxine from the intrathyroidal hormone stores. In addition, there is probably a constant renewal and degradation of the cellular and extracellular thyroxine-binding components. All of these factors must be considered in attempts to extend the available information into any formulation for the intact animal.

The sequence may be written:

$$
\begin{aligned}
& +(\mathrm{TBC})_{\mathrm{EC}} \rightleftharpoons(\mathrm{TBC})_{\mathrm{EC}} \mathrm{T} \mathrm{x} \\
& \mathrm{Tx} \\
& +(\mathrm{TBC})_{\mathrm{c}} \rightleftharpoons(\mathrm{TBC})_{\mathrm{C}} \mathrm{Tx} \rightarrow \mathrm{T}^{\prime}
\end{aligned}
$$

wherein :

$$
\begin{aligned}
& \mathrm{Tx}=\text { Thyroxine } \\
& (\mathrm{TBC})_{\mathrm{EC}}=\text { Extracellular thyroxine-binding }
\end{aligned}
$$

Net irreversible removal of thyroxine from the "thyroxine space" would then be equivalent to $T^{\prime}$ plus the fecal losses of unaltered thyroxine.

Attention in the present and in the preceding communication (6), has been centered upon the binding interactions which determine the reversible distribution of thyroxine. It is tempting to speculate upon the potential mechanisms by which these binding interactions could limit the rate of net thyroxine degradation in vivo.

Various possibilities suggest themselves:

1) The extrathyroidal "thyroxine space" averages ten per cent of body weight in euthyroid humans (19). This would imply that the static cellular/extracellular partition may always favor the extracellular phase and that only trace amounts of cell-bound thyroxine [i.e., $(\mathrm{TBC})_{\mathrm{C}} \mathrm{Tx}$ ] may be present at any single moment. Nonetheless, since cellular "uptake" must precede cellular disposition, ${ }^{12}$ and since "uptake" is determined by the quantitative interactions between $(\mathrm{TBC})_{\mathrm{c}}$, $(\mathrm{TBC})_{\mathrm{EC}}$, and $\mathrm{Tx}$, rate-limiting roles in the formation of $T^{\prime}$ must be assigned to the static concentrations of all three.

2) At any value for the binding equilibrium between $(\mathrm{TBC})_{\mathrm{C}},(\mathrm{TBC})_{\mathrm{EC}}$, and $\left.\mathrm{Tx}: \mathrm{a}\right)$ If rates of cellular degradation exceed those of cellular "uptake," then cell-binding [i.e., $\mathrm{Tx}+(\mathrm{TBC})_{\mathrm{c}} \rightleftharpoons$ $(\mathrm{TBC})_{\mathrm{c}} \mathrm{Tx}$ ] may limit net thyroxine turnover; b) If rates of cellular "uptake" exceed those of cellular degradation, then the rate at which $T^{\prime}$ is formed may delimit the rate at which $\mathrm{Tx}$ is displaced from $(\mathrm{TBC})_{\mathrm{EC}}$ onto $(\mathrm{TBC})_{\mathrm{C}}$. The continued shift to the right would constitute a mechanism whereby cellular degradation of thyroxine could regulate the extracellular turnover of thyroxine.

3) Alternatively, despite a fixed cellular/extracellular distribution, net thyroxine degradation might be delimited by the turnovers of $(\mathrm{TBC})_{\mathrm{c}}$ or $(\mathrm{TBC})_{\mathbf{E C}}$, if : a) $(\mathrm{TBC})_{\mathbf{C}} \mathrm{Tx}$ is degraded as an intact unit, or b) $(\mathrm{TBC})_{\mathbf{E C}} \mathrm{Tx}$ enters the cell as an intact unit, or c) $\mathrm{Tx}$ is made available to the cell

\footnotetext{
12 A relationship between "uptake" and subsequent disposition may also exist at subcellular levels. Klemperer has described a mitochondrial preparation wherein the uncoupling of certain oxidative phosphorylations by mitochondria in vitro (36) is directly correlated with the prior mitochondrial "uptake" of thyroxine from the suspending medium (37).
} 
as a consequence of the disruption of $(\mathrm{TBC})_{\mathbf{E C}}$ at the cell surface. The metabolism of thyroxine would thus be linked to the metabolic fate of the thyroxine-binding components.

To date, the diverse possibilities have not been explored in the intact animal. It does not seem unlikely that they are all concurrently operative in determining the net transcellular exchange of thyroxine. However, for the time being, they must be regarded as hypothetical extrapolations of more limited data, and as such, be subjected to future experimental documentation or refutation.

\section{SUMMARY}

1. The thyroxine-binding proteins of diverse human extracellular fluids have been localized by zone-electrophoretic techniques.

2. In vitro experiments have been conducted to assess the significance of extracellular proteins in the partition of thyroxine between cellular and extracellular phases. Model systems have been devised with surviving slices of liver, heart, and kidney cortex and with suspending media containing human plasma fractions of varied thyroxinebinding potencies.

3. It has been demonstrated that "uptake" of thyroxine by tissues in vitro is not dependent upon cellular metabolic activity, and that thyroxine distribution, in such systems, can be formulated in terms of a reversible binding equilibrium between cellular and extracellular thyroxine-binding components.

4. Possible implications of the data for the net transcellular flux of thyroxine in vivo have been discussed.

\section{ACKNOWLEDGMENTS}

We are indebted to Dr. Eiichi Yamazaki for his help in some of the chromatographic studies and to Miss Alice Ballou for her technical assistance in the nitrogen estimations. Facilities for the fractionation of human plasma were made available through the generosity of Dr. Robert B. Pennell and Dr. John L. Oncley of the Department of Biophysical Chemistry of Harvard Medical School and Dr. John M. Newell and Mr. Roderick D. Dwyer of the Massachusetts Public Health Biologic Laboratories. Tissues from sheep, lambs, beef and calves were obtained through the kind cooperation of $\mathrm{Mr}$. Harold N. Larson and Mr. Fred Johannes of the New England Dressed Meat and Wool Co., Somerville, Mass.

\section{REFERENCES}

1. Gordon, A. H., Gross, J., O'Connor, D., and PittRivers, R., Nature of the circulating thyroid hormone-plasma protein complex. Nature, 1952, 169, 19.

2. Larson, F., Deiss, W. P., and Albright, E. C., Localization of protein-bound radioactive iodine by filter paper electrophoresis. Science, 1952, 115, 626.

3. Winzler, R. J., and Notrica, S. R., Association of thyroxine with plasma proteins. Federation Proc., 1952, 11, 312.

4. Robbins, J., and Rall, J. E., Zone electrophoresis in filter paper of serum $\mathrm{I}^{131}$ after radioiodide administration. Proc. Soc. Exper. Biol. \& Med., 1952, 81, 530.

5. Horst, W., and Rösler, H., Der Transport des Hormonjods in menschlichen Serum untersucht mit Papierelektrophorese und Radiojod. (Zugleich ein Beitrag zur Frage der Existenz von sog. Zwischenfraktionen.) Klin. Wchnschr., 1953 31, 13.

6. Freinkel, N., Dowling, J. T., and Ingbar, S. H., The interaction of thyroxine with plasma proteins: Localization of thyroxine-binding protein in Cohn fractions of plasma. J. Clin. Invest., 1955, 34, 1698.

7. Hughes, W. L., Jr., An albumin fraction isolated from human plasma as a crystalline mercuric salt. J. Am. Chem. Soc., 1947, 69, 1836.

8. Cohn, E. J., Strong, L. E., Hughes, W. L., Jr., Mulford, D. J., Ashworth, J. N., Melin, M., and Taylor, H. L., Preparation and properties of serum and plasma proteins. IV. A system for the separation into fractions of the protein and lipoprotein components of biological tissues and fluids. J. Am. Chem. Soc., 1946, 68, 459.

9. Surgenor, D. M., Strong, L. E., Taylor, H. L., Gordon, R. S., Jr., and Gibson, D. M., The separation of choline esterase, mucoprotein, and metal-combining protein into subfractions of human plasma. J. Am. Chem. Soc., 1949, 71, 1223.

10. Umbreit, W. W., Burris, R. H., and Stauffer, J. F., Manometric Techniques and Tissue Metabolism, 2nd ed., Minneapolis, Burgess Publishing Co., 1949.

11. Mehl, J. W., The biuret reaction of proteins in the presence of ethylene glycol. J. Biol. Chem., 1945, 157, 173.

12. Rutstein, D. D., Ingenito, E. F., and Reynolds, W. E., The determination of albumin in human blood plasma and serum. A method based on the interaction of albumin with an anionic dye-2-(4'-hydroxybenzeneazo) benzoic acid. J. Clin. Invest., 1954, 33, 211.

13. Barker, S. B., Humphrey, M. J., and Soley, M. H., The clinical determination of protein-bound iodine. J. Clin. Invest., 1951, 30, 55.

14. Freinkel, N., and Ingbar, S. H., The relationship between metabolic activity and iodide-concentrating capacity of surviving thyroid slices. J. Clin. Endocrinol. \& Metab., 1955, 15, 442. 
15. Roche, J., Lissitzky, S., and Michel, R., Chromatographic analysis of radioactive iodine compounds from the thyroid gland and body fluids in Glick, D., Ed., Methods of Biochemical Analysis, Vol. I, New York, Interscience Publishers, Inc., 1954, p. 247.

16. Robbins, J., Petermann, M. L., and Rall, J. E., Electrophoresis of the thyroxine-binding protein of serum at $\mathrm{pH}$ 4.5. J. Biol. Chem., 1955, 212, 403.

17. Albright, E. C., Larson, F. C., and Tust, R. H., In vitro conversion of thyroxin to triiodothyronine by kidney slices. Proc. Soc. Exper. Biol. \& Med., 1954, 86, 137.

18. Rall, J. E., Robbins, J., Becker, D., and Rawson, R. W., The metabolism of labeled 1-triiodothyronine, 1-thyroxine and d-thyroxine. J. Clin. Invest., 1953, 32, 596.

19. Ingbar, S. H., and Freinkel, N., Simultaneous estimation of rates of thyroxine degradation and thyroid hormone synthesis. J. Clin. Invest., 1955, 34, 808.

20. Albert, A., and Keating, F. R., Jr., Metabolic studies with $\mathrm{I}^{131}$ labeled thyroid compounds. Comparison of the distribution and fate of radioactive d-1thyroxine after oral and intravenous administration in the human. J. Clin. Endocrinol., 1949, 9, 1406.

21. Myant, N. B., and Pochin, E. E., The metabolism of radiothyroxine in man. Clin. Sc., 1950, 9, 421.

22. Hamolsky, M. W., Freedberg, A. S., Kurland, G. S., and Wolsky, L., The exchangeable thyroid hormonal pool. I. Its magnitude and rate of turnover in various thyroid states in man. J. Clin. Invest., 1953, 32, 453.

23. Berson, S. A., and Yalow, R. S., Quantitative aspects of iodine metabolism. The exchangeable organic iodine pool, and the rates of thyroidal secretion, peripheral degradation and fecal excretion of endogenously synthesized organically bound iodine. J. Clin. Invest., 1954, 33, 1533.

24. Sterling, K., The turnover rate of serum albumin in man as measured by $\mathrm{I}^{131}$-tagged albumin. J. Clin. Invest., 1951, 30, 1228.

25. Berson, S. A., Yalow, R. S., Schreiber, S. S., and Post, J., Tracer experiments with $\mathrm{I}^{131}$ labeled human serum albumin: distribution and degradation studies. J. Clin. Invest., 1953, 32, 746.

26. Armstrong, S. H., Jr., McLeod, K., Wolter, J., and Kukral, J., The persistence in the blood of the radioactive label of albumin, gamma globulins, globulins of intermediate mobility studied with $\mathrm{S}^{35}$ and paper electrophoresis: Methods and preliminary results. J. Lab. \& Clin. Med., 1954, 43, 918.

27. Volwiler, W., Goldsworthy, P. D., MacMartin, M. P., Wood, P. A., Mackay, I. R., and Fremont-Smith, $\mathrm{K}$, Biosynthetic determination with radioactive sulfur of turn-over rates of various plasma proteins in normal and cirrhotic man. J. Clin. Invest., 1955, 34, 1126.

28. Freinkel, N., Schreiner, G. E., and Athens, J. W., Simultaneous distribution of T-1824 and $\mathrm{I}^{131}$-labelled human serum albumin in man. J. Clin. Invest., 1953, 32, 138.

29. Alpers, J. B., and Rall, J. E., The metabolism of iodine in cerebrospinal fluid. J. Clin. Endocrinol. \& Metab., 1955, 15, 1482.

30. Freinkel, N., Dowling, J. T., and Ingbar, S. H., Thyroxine-binding in sera of diverse mammalian species. Manuscript in preparation.

31. Crispell, K. R., and Coleman, J., A study of the relative binding capacity of plasma proteins, intact human red cells, and human red cell stroma for radioactive $\mathrm{I}^{131}$ labelled L-thyroxine. J. Clin. Invest., 1956, 35, 475.

32. Hamolsky, M. W., The plasma protein-thyroid hormone complex in thyrotoxicosis vs. euthyroidism in man. J. Clin. Invest., 1955, 34, 914.

33. Robbins, J., and Rall, J. E., Effects of triiodothyronine and other thyroxine analogues on thyroxine-binding in human serum. J. Clin. Invest., 1955, 34, 1331.

34. Larson, F. C., and Albright, E. C., The specificity of thyroxine binding by serum alpha globulin. Endocrinology, 1955, 56, 737.

35. Klotz, I. M., and Walker, F. M., The binding of organic ions by proteins. Charge and $\mathrm{pH}$ effects. J. Am. Chem. Soc., 1947, 69, 1609.

36. Klemperer, H. G., The uncoupling of oxidative phosphorylation in rat-liver mitochondria by thyroxine, triiodothyronine and related substances. Biochem. J., 1955, 60, 122.

37. Klemperer, H. G., The uptake of thyroxine and triiodothyronine by rat-liver mitochondria. Biochem. J., 1955, 60, 128. 